\title{
Inflammatory Bowel Disease and Sarcopenia: Its Mechanism and Clinical Importance
}

\author{
Hiroki Nishikawa ${ }^{1,2, *}$, Shiro Nakamura ${ }^{1}$, Takako Miyazaki ${ }^{1,2}{ }^{,}$Kazuki Kakimoto ${ }^{1}$, Shinya Fukunishi ${ }^{1,2}$, \\ Akira Asai ${ }^{1} \mathbb{1}$, Shuhei Nishiguchi ${ }^{3}$ and Kazuhide Higuchi ${ }^{1}$ \\ 1 The Second Department of Internal Medicine, Osaka Medical and Pharmaceutical University, \\ Takatsuki 569-8686, Japan; saab460@gmail.com (S.N.); takako.miyazaki@ompu.ac.jp (T.M.); \\ kazuki.kakimoto@ompu.ac.jp (K.K.); shinya.fukunishi@ompu.ac.jp (S.F.); in2108@osaka-med.ac.jp (A.A.); \\ kazuhide.higuchi@ompu.ac.jp (K.H.) \\ 2 The Premier Departmental Research of Medicine, Osaka Medical and Pharmaceutical University, \\ Takatsuki 569-8686, Japan \\ 3 The Department of Internal Medicine, Kano General Hospital, Osaka 531-0041, Japan; \\ nishiguchi@heartfull.or.jp \\ * Correspondence: nishikawa_6392_0207@yahoo.co.jp; Tel.: +81-726-83-1221
}

check for updates

Citation: Nishikawa, H.; Nakamura, S.; Miyazaki, T.; Kakimoto, K.; Fukunishi, S.; Asai, A.; Nishiguchi, S.; Higuchi, K. Inflammatory Bowel Disease and Sarcopenia: Its Mechanism and Clinical Importance. J. Clin. Med. 2021, 10, 4214. https:// doi.org/10.3390/jcm10184214

Academic Editors: Lorenzo Ridola and Andrew Day

Received: 26 July 2021

Accepted: 16 September 2021

Published: 17 September 2021

Publisher's Note: MDPI stays neutral with regard to jurisdictional claims in published maps and institutional affiliations.

Copyright: (c) 2021 by the authors. Licensee MDPI, Basel, Switzerland. This article is an open access article distributed under the terms and conditions of the Creative Commons Attribution (CC BY) license (https:// creativecommons.org/licenses/by/ $4.0 /)$.
Abstract: Malnutrition is a major contributor to muscle loss and muscle dysfunction, known as sarcopenia. Malnutrition is common in patients with inflammatory bowel disease (IBD). IBD includes ulcerative colitis (UC) and Crohn's disease (CD). The number of patients with IBD has recently been increasing. More severe malnutrition is often seen in CD compared to UC, probably due to $\mathrm{CD}$ affecting the main site of nutrient absorption, extensive mucosal lesions, fistulas, short bowel syndrome after resection, or obstruction of the gastrointestinal tract. A recent meta-analysis showed the high prevalence of sarcopenia in patients with IBD, and thus sarcopenia is a very important problem for IBD. Although IBD is more common in younger patients, sarcopenia can develop through a variety of mechanisms, including malnutrition, chronic inflammation, increased inflammatory status in adipose tissue, vitamin deficiency, and imbalance of the muscle-gut axis. In addition, sarcopenia has a negative impact on postoperative complications and hospital stay in patients with IBD. Appropriate intervention for sarcopenia may be important, in addition to clinical remission and endoscopic mucosal healing in patients with IBD. Much more attention will thus be paid to sarcopenia in patients with IBD. In this review, we outline IBD and sarcopenia, based on the current evidence.

Keywords: inflammatory bowel disease; sarcopenia; mechanism; outcome; intervention

\section{Introduction}

Malnutrition is a major contributor to muscle loss and muscle dysfunction, known as sarcopenia, and it is defined as "a condition with altered body composition, impaired physical performance, and poor clinical outcome, due to inadequate nutrient intake or uptake" [1]. Malnutrition is common in patients with inflammatory bowel disease (IBD) [1]. Sarcopenia was first reported by Rosenburg in 1989 and defined as "aging-related loss of muscle mass" [2]. However, it has been shown that sarcopenia can also develop as a result of malignancies, malnutrition, inactivity, infection, and chronic inflammation (i.e., secondary sarcopenia) [3]. In the recent Asian Working Group for Sarcopenia (AWGS) and European Working Group of Sarcopenia in Older People (EWGSOP) definitions, loss of muscle mass accompanied by loss of muscle strength and physical performance is judged to be severe sarcopenia $[4,5]$.

IBD includes ulcerative colitis (UC) and Crohn's disease (CD). UC is an idiopathic, chronic inflammatory disease that affects the colonic mucosa continuously, from the rectum to the colon [6,7]. CD, on the other hand, is a progressive inflammatory disease that involves all layers of the gastrointestinal (GI) tract and can occur in any part of the GI 
tract, with complications such as stenosis, fistulae, and abscess occurring at a higher rate than UC [8,9]. IBD is an acute and chronic disease with exacerbations and remissions, and there is still no curative therapy for CD. It is widely known that CD shows a progressive tendency for decline in GI function through the formation of GI complications, such as severe stenosis, fistulae, and abscesses, during its clinical course, with repeated relapses and remissions, resulting in a high rate of indication for intestinal resection $[8,9]$.

It is not uncommon for activity of daily life (ADL) to decline due to resistance to treatment in patients with CD [8,9]. Due to these characteristics of the clinical course of $\mathrm{CD}$, control of the activity of CD alone is not sufficient as a therapeutic goal. The importance of achieving mucosal healing earlier in the course of the disease has been shown to correlate with an improved long-term prognosis [8,9]. UC, on the other hand, can be cured by total colonic resection, but it is important to maintain the remission stage with appropriate pharmacological intervention [6,7]. It is also important to avoid systemic administration of corticosteroids, as much as possible with adequate 5-aminosalicylic acid (5-ASA) preparations. For refractory patients with UC, early intervention with appropriate alternative therapies is required to wean off corticosteroids, rather than continuing steroid therapy indiscriminately as a basic treatment strategy [6,7]. Corticosteroids promote protein catabolism in skeletal muscle by the crosstalk between the glucocorticoid receptor and mechanistic target of the rapamycin complex 1 (mTORC1) [10]. mTORC1 acts not only to promote anabolism, but also to inhibit catabolism [10].

The number of patients with IBD has been increasing in recent years [11]. In 2014, the annual prevalence rates of UC and CD per 100,000 persons were 172.9 (192.3 in males and 154.5 in females) and 55.6 (79.5 in males and 33.1 in females), respectively [11]. As mentioned earlier, the basic treatment of UC is pharmacotherapy, and nutritional therapy itself does not lead to the remission stage of UC. The treatment of CD, on the other hand, involves a two-pronged approach: pharmacotherapy and nutritional therapy [6-9]. Intravenous nutrition in CD is expected to have an anti-inflammatory effect, by not exposing the GI tract to dietary antigens and fats [8]. If the Crohn's disease is highly active and the nutritional status is markedly deteriorated, fasting is required for its management, and total parenteral nutrition is usually indicated $[8,9]$.

More severe malnutrition is often seen in CD compared to UC [12]. This may be due to $\mathrm{CD}$ affecting the main site of nutrient absorption, extensive mucosal lesions, fistulas, short bowel syndrome after resection, or obstruction of the GI tract [12]. In CD, cytokines, such as interleukin-6 (IL-6), which are directly involved in the pathogenesis of the disease, inhibit the albumin promoter and induce hypoalbuminemia or act on the iron metabolism, resulting in anemia [8]. On the other hand, recent remarkable advances in therapeutic modalities for patients with IBD, such as antibody therapy and molecular targeted therapies, which focuses on inhibiting the specific molecular targets associated with inflammation of the intestinal mucosa, have been made, while the prevalence and prognostic impact of sarcopenia in IBD has not received much attention. A recent meta-analysis showed that $52 \%$ of patients with CD and $37 \%$ of patients with UC have sarcopenia [13], while sarcopenia seems to be a very important problem for patients with IBD. In patients with ankylosing spondylitis, which is an occasional complication of IBD, 34.3\% were reported to have sarcopenia [14]. In addition, sarcopenia has a negative impact on postoperative complications and hospital stay in patients with IBD [15]. At the end of 2020, Selecting Therapeutic Targets in Inflammatory Bowel Disease (STRIDE)-II was published, which advocates not only clinical remission and mucosal healing as treatment goals for patients with IBD, but also the avoidance of structural destruction and dysfunction of the intestinal tract, as well as improvement of physical function, as long-term treatment goals [16]. These statements suggest that sarcopenia is a very important condition in patients with IBD. In this review, we will outline IBD and sarcopenia based on the current evidence. 


\section{Methods and Frequency of Sarcopenia Assessment in Patients with IBD}

Table 1 shows the evaluation methods and frequency of sarcopenia reported in recent years in patients with IBD [17-32]. In more than half of the reports, computed tomography (CT, L3 level) is used to assess sarcopenia, but many reports only use muscle mass assessment to determine sarcopenia, while a few include grip strength and walking speed in the assessment of sarcopenia [17]. Furthermore, unlike primary sarcopenia [4,5], no reference values have been established for muscle mass, grip strength, or walking speed in patients with IBD. Moreover, screening tools for sarcopenia such as SARC-F (a questionnaire consisting of five questions) as recommended by AWGS and EWGSOP, are not available in patients with IBD $[4,5,33]$. On the other hand, the usefulness of skeletal muscle signal intensity in magnetic resonance imaging (MRI) T1-weighted images for the clinical outcomes in patients with CD has also been reported [34]. It has been reported that muscle mass in MRI correlates well with lean body mass using a bioelectrical impedance analysis (BIA) method in pediatric patients with UC [35]. The frequency of sarcopenia in patients with IBD varies from report to report, ranging from about $20-70 \%$, as shown in Table 1 . This may be due to differences in the definition of sarcopenia and differences in body size between Western and Asian patients with IBD. In acute severe UC, the frequency of sarcopenia was reported to be 70\% [23]. In 29 pediatric patients with UC, $62 \%$ were reported to have sarcopenia [26].

Table 1. Prevalence of sarcopenia in adult or pediatric patients with inflammatory bowel diseases reported in recent years.

\begin{tabular}{|c|c|c|c|c|c|c|c|}
\hline Author [Ref.] & Country & Year & Disease & $N$ & $\begin{array}{c}\text { Age } \\
\text { (Mean, } \\
\text { Median } \\
\text { or } \\
\text { Range) }\end{array}$ & $\begin{array}{l}\text { Assessment } \\
\text { Modality }\end{array}$ & $\begin{array}{l}\text { Sarcopenia } \\
(\%)\end{array}$ \\
\hline Ünal et al. [17] & Turkey & 2021 & $\mathrm{UC}$ or $\mathrm{CD}$ & 344 & 49 & EWGSOP2 & 41.3 \\
\hline Boparai et al. [18] & India & 2021 & CD & 44 & 34 & CT (L3) & 43 \\
\hline Ge et al. [19] & China & 2021 & $\begin{array}{c}\text { Acute } \\
\text { severe UC }\end{array}$ & 233 & 43.6 & CT (L3) & 50.2 \\
\hline Celentano et al. [20] & UK & 2020 & CD & 31 & 46 & MRI (L3) & 38 \\
\hline Lee et al. [21] & Korea & 2020 & $\mathrm{CD}$ & 79 & 29 & $\mathrm{CT}$ (L3) & 50 \\
\hline Grillot et al. [22] & France & 2020 & CD & 88 & 35 & CT (L3) & 58 \\
\hline Cushing et al. [23] & USA & 2018 & $\begin{array}{c}\text { Acute } \\
\text { severe UC }\end{array}$ & 89 & 43 & CT (L3) & 70 \\
\hline Mager et al. [24] & Canada & 2018 & $\begin{array}{l}\text { Pediatric } \\
\text { UC or CD }\end{array}$ & 85 & 5 to 18 & DXA & 23.5 \\
\hline Thiberge et al. [25] & France & 2018 & CD & 149 & 41 & CT (L3) & 33.6 \\
\hline Dedhia et al. [26] & USA & 2018 & $\begin{array}{l}\text { Pediatric } \\
\text { UC }\end{array}$ & 29 & 15.9 & MRI (L3) & 62 \\
\hline Fujikawa et al. [27] & Japan & 2017 & UC & 69 & 39.8 & CT (L3) & 25.9 \\
\hline Csontos et al. [28] & Hungary & 2017 & $\mathrm{CD}$ & 126 & 34 & BIA & 29.4 \\
\hline Holt et al. [29] & Australia & 2017 & $\mathrm{CD}$ & 44 & 38 & $\begin{array}{l}\text { CT or MRI } \\
\text { (L3) }\end{array}$ & 41 \\
\hline Bamba et al. [30] & Japan & 2017 & $\mathrm{CD}$ & 43 & 29 & CT (L3) & 37 \\
\hline Zhang et al. [31] & China & 2017 & $\mathrm{UC}$ or $\mathrm{CD}$ & 204 & 25 & CT (L3) & $\begin{array}{l}\text { UC: } 27.3 \\
\text { CD: } 59.0\end{array}$ \\
\hline Cravo et al. [32] & Portugal & 2017 & $\mathrm{CD}$ & 71 & 43 & CT (L3) & 31 \\
\hline
\end{tabular}

$\overline{\mathrm{UC}}$, ulcerative colitis; CD, Crohn's disease; EWGSOP2, European Working Group for Sarcopenia in Older People 2; CT, computed tomography; MRI, magnetic resonance imaging; DXA, dual-energy X-ray absorptiometry; BIA, bioelectrical impedance analysis.

\section{Mechanisms of Sarcopenia in Patients with IBD}

\subsection{Malabsorption}

Malabsorption syndrome is a condition caused when nutrients in the food are not properly absorbed in the small intestine for various reasons and is directly related to the development of sarcopenia [36]. IBD is one of the most common diseases that cause malabsorption [37]. Increased inflammation in the gut releases inflammatory mediators such as TNF $\alpha$ and IL-6, which increase intestinal permeability and cause local and systemic inflammatory effects [36,38]. Intestinal inflammation shortens the contact time between nutrients and the intestinal mucosal surface, exacerbating malabsorption and reducing the absorption of amino acids [36]. Since amino acids are a major anabolic signal in muscle, decreased amino acid absorption will induce sarcopenia [38]. In particular, leucine deficiency 
causes a significant reduction in muscle protein synthesis [39]. In a recent randomized controlled trial (RCT), the benefit of leucine supplementation on sarcopenia in the elderly was reported [39]. On the other hand, resection of the intestine reduces the surface area of the mucosa that can absorb nutrients, resulting in malnutrition [37]. Vomiting, diarrhea, anorexia, appetite loss, and side effects of medications (e.g., pancreatitis) can also cause malabsorption [37]. Medications for IBD can cause pancreatitis, especially thiopurines and mesalazine [40]. Trace element deficiencies due to malabsorption syndrome, especially zinc deficiency, may be associated with the development of sarcopenia [41-43].

\subsection{Chronic Inflammation}

Chronic inflammation is thought to play an important role in the development of sarcopenia in IBD. Patients with IBD are accompanied by a systemic increase in proinflammatory cytokines such as interferon (IFN) $\gamma$, IL-1, IL-6, and especially tumor necrosis factor (TNF) $\alpha$ [44]. Inflammatory cytokines are associated with protein catabolism and reduced muscle protein synthesis [44], while TNF $\alpha$ induces muscle protein degradation by inhibiting the anabolic mTORC1 pathway. In addition, the stimulation of muscle atrophy F-box (MAFBx) and muscle RING finger 1 (MURF-1) by TNF $\alpha$ promotes muscle protein degradation [45]. TNF $\alpha$ also increases reactive oxidative stress, activates the nuclear factor kappa-light-chain-enhancer of the activated B cells (NF-kB) pathway, and induces further downstream inflammation [46]. Inflammatory cytokines are known to activate NF- $\kappa B$ and the ubiquitin-proteasome system, as well as to reduce the levels of insulinlike growth factor-1 (IGF-1) in the plasma and muscle [47]. Decreased IGF-1 results in decreased activation of the phosphoinositide 3-kinase (PI3K) pathway, reduced stimulation of mTORC1, and decreased muscle protein synthesis. NF- $\mathrm{kB}$ and TNF- $\alpha$ induce myostatin, an inhibitor of muscle protein synthesis, and myostatin inhibits mTORC1 and activates MURF-1 and MAFBx [48]. In pediatric patients with IBD, an association between low serum IGF-1 levels and decreased QOL has been noted [47]. In patients with CD, the association between muscle fatigue and low serum IGF-1, high IL-6, etc. has been observed [49], and IGF-1 is inversely associated with disease activity [50].

\subsection{Role of Adipose Tissue}

It is known that the adipokines secreted by adipocytes play an essential role in the homeostasis of energy metabolism, but they are also involved in the regulation of the immune system and in the homeostasis of muscle proteins [51]. It has been known for a long time that in patients with CD, increased mesenteric adipose tissue is observed at a high frequency just below the ulcer lesion, and more visceral fat, especially mesenteric fat, has been observed on CT scans in CD than in UC [52]. The term "creeping fat" refers to the fat in the mesentery that occupies more than half of the area surrounding the inflamed bowel [52]. In patients with IBD, mesenteric fat does not necessarily correlate with body mass index (BMI), as it can increase with increased inflammatory status, even in the absence of elevated BMI, and thus an increase in mesenteric fat is often overlooked in patients with IBD and normal or low BMI. It is important to note that in patients with IBD and sarcopenia, where BMI is apparently preserved due to increased fat, loss of muscle mass may be overlooked [53]. Although BMI is a globally accepted screening tool for assessing nutritional status, it may not be a reliable indicator of malnutrition in patients with IBD. In a recent review by Adams et al. [54], 49\% of the study cohort with IBD had sarcopenia, while $41.4 \%$ of these patients had normal weight and $19.5 \%$ were overweight or obese. In addition, adipocytes in the mesentery are directly involved in the induction of inflammatory responses in intestinal epithelial cells [55]. Adipocytes produce pro-inflammatory cytokines, such as free fatty acids, TNF $\alpha$, and IL- 6 , and these cytokines are known to induce inflammatory responses by activating transcription factors, such as $\mathrm{NF}-\mathrm{\kappa B}$, and signal transducer and activator of transcription 3 (STAT3) [55]. Inflammation of adipose tissue is associated with the exacerbation of IBD and may be involved in the development of sarcopenia. 


\subsection{Vitamin D Deficiency}

Much attention has been paid to the role of vitamin D in patients with sarcopenia [56]. Vitamin D is fat-soluble and plays many important roles in skeletal muscle, including maintaining muscle contractile excitability via intracellular calcium, the proliferation and differentiation of skeletal muscle stem cells, and the maintenance of muscle function [56]. Vitamin D deficiency has been correlated with the risk of diseases such as sarcopenia, cardiovascular disease, obesity, osteoporosis, and cancer [57]. Vitamin D deficiency is more common in patients with IBD with low lipid intake or with malabsorption, and 30-47\% of patients with IBD have been shown to have vitamin D deficiency [58]. A link between vitamin D receptor (VDR) and muscle protein anabolic signaling has been reported as the mechanism by which vitamin D deficiency is associated with muscle loss [59]. In addition to its direct effects on skeletal muscle, VDR is known to affect mitochondrial function, and decreased VDR results in decreased oxidative phosphorylation [60]. Mitochondrial dysfunction increases the production of reactive oxygen species that adversely affect skeletal muscle and can lead to sarcopenia [61]. Vitamin D plays a role in maintaining the homeostasis of the mucosal barrier by modulating immune responses, and vitamin $\mathrm{D}$ deficiency may increase susceptibility to mucosal damage, worsen the disease status of IBD, and induce sarcopenia [62]. Pediatric patients with CD and vitamin D deficiency are at high risk of sarcopenia [24]. Vitamin D deficiency is also a risk for osteosarcopenia [63]. On the other hand, in patients with UC, where the appearance of damaged lesions in the duodenum and small intestine is rare, vitamin deficiency is less frequent than in CD [64]. However, the absorption of vitamin D may be reduced due to interaction with 5-ASA preparations [65]. In patients with IBD, urinary excretion of calcium is enhanced during corticosteroid administration, increasing the risk of osteoporosis, and increased protein catabolism contributes to sarcopenia [65]. When IBD is active, the fat-soluble vitamins, vitamin A and vitamin E are decreased, as well as vitamin D [66]. Decreased serum levels of vitamins $A$ and $E$ have also been found in 16\% of patients with CD [67]. A recent meta-analysis showed the benefit of vitamin D preparations in patients with UC [66].

A report followed 965 patients with IBD (61.9\% with CD and 38.1\% with UC) for 5 years; classified them into low and normal groups, according to their mean serum 25-hydroxyvitamin $\mathrm{D}$ levels during follow-up; and examined their relationship with drug use, medical care utilization, inflammatory markers, pain, and disease activity scores [68]. A total of $29.9 \%$ of the patients were classified as a low vitamin D group, and those in the low vitamin D group had a significantly higher frequency of corticosteroids, biologics and analgesics, CT scans, emergency visits, hospitalization, and need for surgery than those in the normal vit-D group (all $p<0.05$ ). There was also a significant worsening of pain, disease activity score, and health-related quality of life (QOL) in the low vitamin D group (all $p<0.05$ ) [68]. Vitamin D deficiency in patients with IBD is closely associated with clinical outcomes. On the other hand, a correlation between vitamin B12 deficiency and sarcopenia in the elderly has been reported, but not in patients with IBD [69].

\subsection{Muscle-Gut Axis}

The muscle-gut axis plays an essential role in skeletal muscle homeostasis [70]. A healthy gut microbiota regulates the immune homeostasis, metabolic homeostasis, and gene expression through the production of short-chain fatty acids (SCFAs) and antioxidants and allows immunocompetent cells in the mucosa to produce pro-inflammatory cytokines [70]. The gut microbiota has a direct influence on the bioavailability of amino acids [71], and some gut bacteria are derived from oral intake, which plays an essential role in the quantity and diversity of the gut microbiota [71]. The gut microbiota transmits nutrient signals and produces mediators for skeletal muscle homeostasis. SCFAs act on skeletal muscle mitochondria and affect muscle protein synthesis [72]. On the other hand, more than $99 \%$ of intestinal bacteria belong to the four phylums: Firmicutes, Bacteroidetes, Proteobacteria, and Actinobacteria [73]. There are several bacteria that have been identified to play a potential role in skeletal muscle function [74]. For example, bifidobacteria (Actinobacte- 
ria phylum) promote the breakdown of proteins into amino acids in the gut, produce SCFAs for energy production, stimulate the IGF-1/mTORC1 pathway, and promote the expression of genes involved in muscle protein synthesis [75]. In conditions with a reduced quantity and diversity of gut microbiota (i.e., dysbiosis), increased intestinal permeability leads to elevated myostatin in muscle and induces sarcopenia [76]. Patients with IBD have a high incidence of dysbiosis [77]. In patients with UC, the production of inflammatory cytokines such as TNF $\alpha$ can be enhanced by the invasion of Fusobacterium varium (F. varium), a commensal bacterium, and this has been suggested to be related to the development of UC [78]. F. varium has the ability to adhere to, and invade, colonic mucosal cells [78], and elevated pro-inflammatory cytokines caused by F. varium may be associated with the development of sarcopenia. Antibody titers to $F$. varium in patients with UC are significantly higher than those in CD and healthy individuals [79]. In contrast, CD-associated Escherichia coli with pro-inflammatory properties include adhesive invasive Escherichia coli (AIEC). It has been shown that AIEC is increased in approximately $38 \%$ of patients with active CD, compared to $6 \%$ of healthy individuals [77].

The mechanism by which patients with IBD develop sarcopenia is shown in Figure 1.

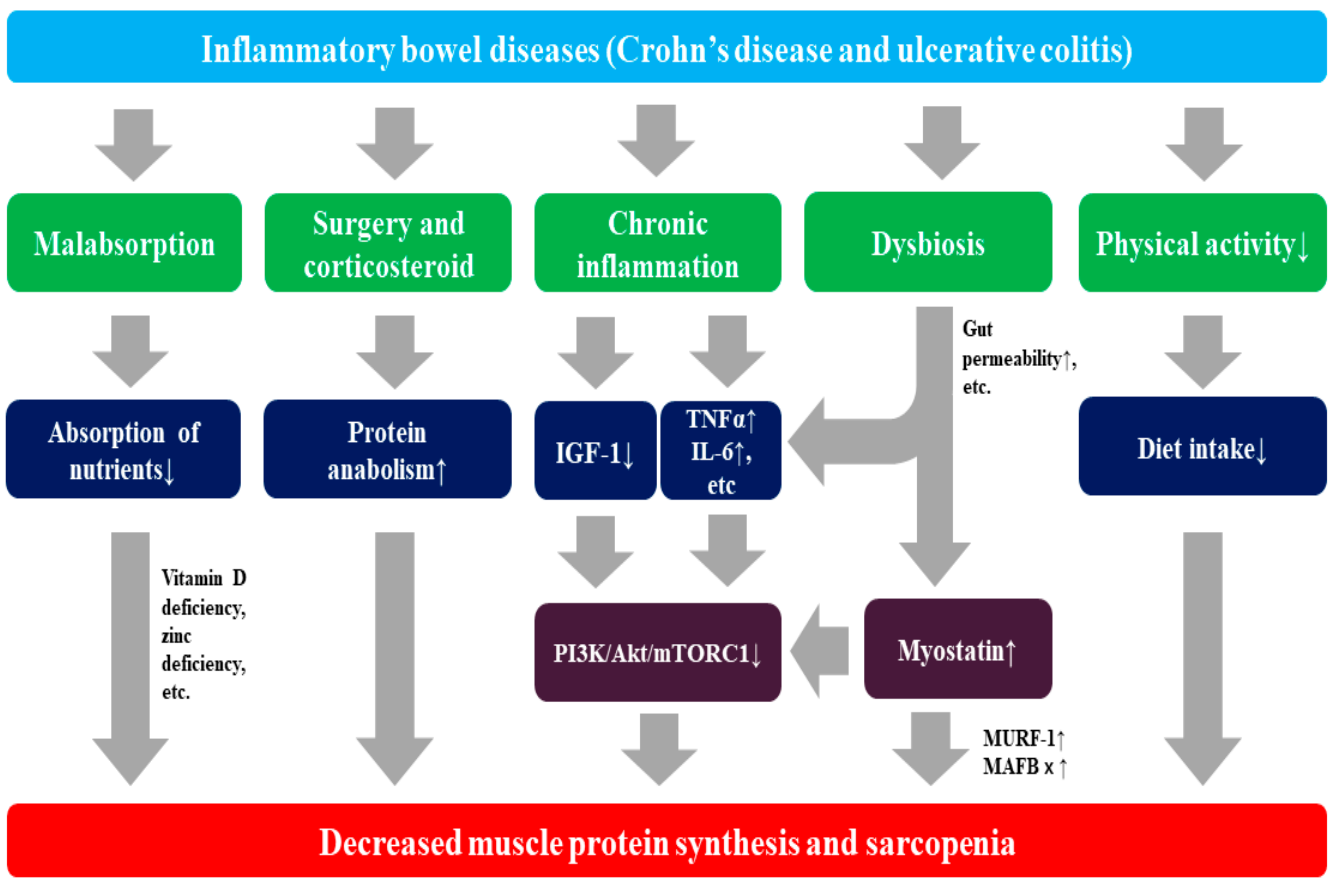

Figure 1. Mechanism for sarcopenia in patients with inflammatory bowel disease (IBD). IBD can cause sarcopenia through a variety of pathologies and immune responses. TNF $\alpha$ : tumor necrosis factor $\alpha$, IGF-1: insulin-like growth factor 1, mTORC1: mechanistic target of the rapamycin complex 1, IL-6: interleukin-6, PI3K: phosphoinositide 3-kinase, MURF-1: muscle RING finger 1, MAFB x: muscle atrophy F-box.

\section{Prognostic Impact of Sarcopenia in Patients with IBD}

Table 2 shows reports on the relationship between sarcopenia and prognoses in patients with IBD $[19,23,26,27,30-32,54,80-87]$. There have been numerous reports that sarcopenia is a poor prognostic factor in patients with IBD undergoing surgery $[19,26,27,30,31,54,81-86]$. There are also reports that sarcopenia correlates with the severity of IBD $[31,80]$. There are reports that sarcopenia is helpful in determining treatment decisions for patients with IBD [23], that skeletal muscle adiposity is associated with prolonged hospitalization and rehospitalization in patients with IBD [83], and that sarcopenia is associated with osteoporosis in patients with IBD [87]. It has been reported that sarcopenia is a risk factor for the development of nonalcoholic fatty liver disease (NAFLD) in patients with IBD [88]. Kang et al. reported that among 443 patients with IBD, NAFLD was found in $11.1 \%$ and sarcopenia in $34.9 \%$, with a higher incidence of 
sarcopenia in patients with NAFLD (51.0\%), compared to patients with non-NAFLD (33.0\%, $p=0.019$ ). In their multivariate analysis, metabolic syndrome (hazard ratio $(\mathrm{HR})=8.63$ ), small bowel resection $(\mathrm{HR}=3.45)$, hyperuricemia $(\mathrm{HR}=4.66)$, and sarcopenia $(\mathrm{HR}=2.99)$ were independent adverse predictors for NAFLD in patients with IBD [88]. The prevalence of obesity in patients with IBD is reported to be 15-40\% [89]. On the other hand, the number of elderly onset patients with UC has been increasing in recent years [90,91]. In an aging society, frailty is an important social problem, as well as sarcopenia [92]. Like sarcopenia, frailty also affects the prognosis of patients with IBD, such as rehospitalization, death, and severe infections [93-96]. The comprehensive assessment of physical frailty, cognitive frailty, and social frailty in elderly patients with IBD seems to be important for the current situation, where the number of elderly patients with IBD is increasing [96,97].

Table 2. Prognostic impact of sarcopenia in patients with inflammatory bowel disease.

\begin{tabular}{|c|c|c|c|c|}
\hline Author [Ref.] & Country & Year & $N$ (Disease) & Notable Findings \\
\hline Zager et al. [82] & Israel & 2021 & $121(\mathrm{CD})$ & $\begin{array}{c}\text { Psoas muscle area is an easily measured } \\
\text { radiological parameter linked to postoperative } \\
\text { complications in patients with CD receiving } \\
\text { bowel resection. }\end{array}$ \\
\hline Ge et al. [19] & China & 2021 & 233 (UC) & $\begin{array}{l}\text { Sarcopenia is helpful for predicting the clinical } \\
\text { course and postoperative outcomes in patients } \\
\text { with acute severe UC. }\end{array}$ \\
\hline Atlan et al. [80] & Israel & 2021 & $\begin{array}{l}32 \text { (UC), } \\
69 \text { (CD) }\end{array}$ & $\begin{array}{c}\text { Sarcopenia involves significant correlation } \\
\text { with the severity of pediatric IBD and serves as } \\
\text { a predictor for adverse clinical disease } \\
\text { outcome. }\end{array}$ \\
\hline Bamba et al. [81] & Japan & 2020 & $\begin{array}{l}99(\mathrm{CD}) \\
88(\mathrm{UC})\end{array}$ & $\begin{array}{l}\text { Low muscle volume and low visceral adipose } \\
\text { tissue volume negatively affect the long-term } \\
\text { outcome of intestinal resection. }\end{array}$ \\
\hline Galata et al. [83] & Germany & 2020 & $230(\mathrm{CD})$ & $\begin{array}{l}\text { SMI was the only significant adverse factor for } \\
\text { Clavien-Dindo complications grade } \geq \text { III. }\end{array}$ \\
\hline Dedhia et al. [26] & USA & 2018 & 29 (UC) & $\begin{array}{l}\text { Paraspinous muscle area on MRI is associated } \\
\text { with complications and increased hospital stay } \\
\text { after colectomy in patients with pediatric UC. }\end{array}$ \\
\hline Cushing et al. [23] & USA & 2018 & 89 (UC) & $\begin{array}{l}\text { Sarcopenia, as determined on abdominal CT, } \\
\text { was a novel predictor of need for rescue } \\
\text { therapy in hospitalized patients with UC. }\end{array}$ \\
\hline Stephen et al. [84] & Ireland & 2018 & $\begin{array}{l}21 \text { (UC), } 52(\mathrm{CD}) \\
4(\mathrm{Im})\end{array}$ & $\begin{array}{l}\text { Myosteatosis was associated with prolonged } \\
\text { hospital stay and increased 30-day hospital } \\
\text { readmission rates in a multivariate analysis. }\end{array}$ \\
\hline Adams et al. [54] & USA & 2017 & 14 (UC), 76 (CD) & $\begin{array}{l}\text { Sarcopenia was a predictor for surgical } \\
\text { resection in patients with IBD with a body } \\
\text { mass index } \geq 25 \mathrm{~kg} / \mathrm{m}^{2} \text {. }\end{array}$ \\
\hline Pederson et al. [85] & USA & 2017 & $\begin{array}{l}51 \text { (UC), } 127 \\
\text { (CD) }\end{array}$ & $\begin{array}{l}\text { In IBD patients younger than } 40 \text { years, } \\
\text { sarcopenia affects surgical outcomes. }\end{array}$ \\
\hline Fujikawa et al. [27] & Japan & 2017 & 69 (UC) & $\begin{array}{c}\text { Sarcopenia is a predictor for surgical site } \\
\text { infection after pouch surgery in patients with } \\
\text { UC. }\end{array}$ \\
\hline Zhang et al. [31] & China & 2017 & 99 (UC) & $\begin{array}{l}\text { SMI correlated significantly with UC disease } \\
\text { activity. Sarcopenia (HR }=8.49, p=0.007) \text { was } \\
\text { an adverse independent predictor of high } \\
\text { Mayo score in patients with UC. Patients with } \\
\text { UC and sarcopenia had a high probability of } \\
\text { need for colectomy. }\end{array}$ \\
\hline Bamba et al. [30] & Japan & 2017 & 29 (UC),43 (CD) & $\begin{array}{l}\text { The cumulative operation-free survival rate } \\
\text { was significantly lower in patients with IBD } \\
\text { and sarcopenia than in all patients with IBD. }\end{array}$ \\
\hline Cravo et al. [32] & Portugal & 2017 & $71(\mathrm{CD})$ & $\begin{array}{l}\text { A lower muscle attenuation and a high visceral } \\
\text { fat index were associated with disease severity } \\
\text { in patients with CD. }\end{array}$ \\
\hline Zhang et al. [86] & China & 2017 & $114(\mathrm{CD})$ & $\begin{array}{l}\text { The prevalence of sarcopenia is higher in } \\
\text { patients with CD requiring bowel resection. It } \\
\text { significantly elevates the risk of major } \\
\text { postoperative complications. }\end{array}$ \\
\hline Bryant et al. [87] & Australia & 2015 & 42 (UC), 95 (CD) & $\begin{array}{l}\text { Low lean mass and sarcopenia are common in } \\
\text { patients with IBD and important to recognize, } \\
\text { as they predict osteopenia or osteoporosis. }\end{array}$ \\
\hline
\end{tabular}

$\overline{\mathrm{UC}}$, ulcerative colitis; CD, Crohn's disease; Im, Intermediate; IBD, inflammatory bowel disease; CT, computed tomography; MRI, magnetic resonance imaging; SMI, skeletal muscle index; HR, hazard ratio.

\section{Intervention for Patients with IBD and Sarcopenia}

\subsection{Nutritional Intervention}

There is increasing evidence to support nutritional interventions for maintaining muscle mass and increasing muscle strength and function in elderly people with sarcopenia [98]. 
An important nutrient to counteract sarcopenia is dietary protein, and in patients with IBD, a protein intake of $1.2-1.5 \mathrm{~g} / \mathrm{kg} /$ day is often recommended during the active phase of IBD [99]. As mentioned earlier, STRIDE-II advocates the avoidance of structural destruction and dysfunction of the intestinal tract, and improvement of physical function and QOL or ADL as long-term therapeutic goals for patients with IBD, so nutritional intervention in patients with IBD and sarcopenia is highly significant [16]. However, while optimizing nutritional status may be an effective countermeasure against sarcopenia in IBD, there is currently no established evidence on the role of specific diets or supplements for the prevention and treatment of sarcopenia in IBD. On the other hand, recent advances in nutritional therapy for postoperative short bowel syndrome for Crohn's disease can inhibit the exacerbation of sarcopenia [100].

\subsection{Exercise}

Exercise, both aerobic and resistance, is a well-established way to improve muscle mass and strength [101]. Physical activity is now recognized as having an anti-inflammatory effect [102]. Patients with IBD often suffer from lack of physical activity, and thus physical exercise for patients with IBD could be used as supportive intervention [103]. However, unlike healthy individuals, there are concerns about exercise intervention for patients with IBD. Although there are a number of studies that demonstrated the safety and efficacy of exercise interventions in patients with IBD, these studies have often been conducted in patients with IBD with mild disease status or in remission, and a thorough evaluation is required to determine whether exercise interventions in patients with active IBD are an aggravating factor for IBD [103-109]. The significance of exercise intervention for improving sarcopenia in patients with IBD with higher disease activity is unknown [104-109].

\subsection{Pharmacological Intervention}

There have been several reports on drug interventions in patients with IBD and sarcopenia. Infliximab improves sarcopenia in patients with CD [110]. In a study of 19 patients with $C D$, both muscle mass and muscle strength improved significantly after 24 weeks of infliximab treatment, and IL6 was significantly reduced [110]. Loss of skeletal muscle mass correlates with UC activity and improves after pharmacological therapy and colorectal surgery [31]. Several studies have demonstrated the benefits of vitamin D supplementation in patients with IBD, but only a limited number of studies have demonstrated the effects of vit-D supplementation on muscle mass and function. While, vitamin D supplementation improves muscle strength in presarcopenic elderly people [111], healthy people between the ages of 18 and 40 [112], and postmenopausal women [74]. There are reports that vitamin D supplementation in pediatric patients with IBD improved bone mineral density and muscle strength [113], but data in adult patients with IBD are lacking. Vitamin D supplementation in patients with IBD also improves dysbiosis [114]. VDRs are involved in the regulation of $\mathrm{T}$ cell and Paneth cell function and regulate the release of antimicrobial peptides in gut bacteria-host interactions [114]. On the other hand, mucosal healing and disease remission in patients with IBD can significantly improve oral feeding and nutritional status, and prevent muscle loss. It should also be noted that biologics such as anti-TNF- $\alpha$ antibodies, anti- $\alpha 4 \beta 7$ integrin antibodies, and Janus kinase (JAK) inhibitors improve the mucosal healing rate for moderate to severe UC, allowing early feeding and contributing to the improvement of sarcopenia [7,9]. Table 3 summarized the results of interventions for patients with IBD, focusing on sarcopenia. The number of reported studies is small. 
Table 3. The results of interventions for IBD patients focusing on sarcopenia.

\begin{tabular}{|c|c|c|c|c|c|}
\hline Author [Ref.] & Year & Disease & $N$ & Intervention & Outcome \\
\hline $\begin{array}{l}\text { Sigurdsson } \\
\text { et al. [107] }\end{array}$ & 2021 & $\begin{array}{l}\text { Young } \\
\text { IBD }\end{array}$ & 41 & $\begin{array}{l}\text { Physical } \\
\text { exercise }\end{array}$ & $\begin{array}{l}\text { Physical exercise is associated with } \\
\text { beneficial bone mineral density and body } \\
\text { composition in young patients with IBD. }\end{array}$ \\
\hline $\begin{array}{c}\text { Seeger et al. } \\
\text { [108] }\end{array}$ & 2020 & $\begin{array}{l}\text { Mild } \\
\text { CD }\end{array}$ & 45 & $\begin{array}{l}\text { Physical } \\
\text { exercise }\end{array}$ & $\begin{array}{c}\text { The maximal and average strength in the } \\
\text { upper and lower extremities increased } \\
\text { significantly }\end{array}$ \\
\hline $\begin{array}{c}\text { Jones et al. } \\
\text { [109] }\end{array}$ & 2020 & $\begin{array}{l}\text { Stable } \\
\text { CD }\end{array}$ & 47 & $\begin{array}{l}\text { Physical } \\
\text { exercise }\end{array}$ & $\begin{array}{l}\text { The exercise group had superior values } \\
\text { for all muscle function outcomes and } \\
\text { lower fatigue severity. }\end{array}$ \\
\hline $\begin{array}{l}\text { Hradsky et al. } \\
\text { [113] }\end{array}$ & 2017 & $\begin{array}{c}\text { Pediatric } \\
\text { IBD }\end{array}$ & 55 & $\begin{array}{c}2000 \text { IU of } \\
\text { Cholecalciferol }\end{array}$ & $\begin{array}{c}\text { Cholecalciferol substitution was } \\
\text { positively associated with trabecular } \\
\text { bone mineral density and maximal } \\
\text { muscle power. }\end{array}$ \\
\hline $\begin{array}{l}\text { Subramaniam } \\
\text { et al. [110] }\end{array}$ & 2015 & $\mathrm{CD}$ & 19 & infliximab & $\begin{array}{l}\text { Muscle mass and muscle strength } \\
\text { improved significantly. }\end{array}$ \\
\hline
\end{tabular}

IBD, inflammatory bowel disease; CD, Crohn's disease.

\section{Final Remarks}

In this review, IBD and sarcopenia were outlined. Although IBD is more common in younger patients, sarcopenia can develop through a variety of mechanisms, including malnutrition and chronic inflammation. It should be noted that the prevalence of patients with IBD is increasing significantly worldwide, and a certain number of these patients have sarcopenia. It should also be noted that the number of elderly patients with UC who are prone to the complications of sarcopenia and/or frailty is increasing. The standard values of the evaluation items (grip strength, muscle mass, etc.) for determining sarcopenia in patients with IBD have not been established, and this is an issue for the future. Evidence is accumulating that sarcopenia is a prognostic factor in patients with IBD, and appropriate intervention for sarcopenia may be important, in addition to clinical remission and endoscopic mucosal healing. In particular, there is an urgent need to establish exercise therapy in patients with IBD and sarcopenia. It is hoped that more evidence will be collected on interventions for patients with IBD and sarcopenia.

Author Contributions: Writing the article: H.N. Review and editing the article: S.N. (Shiro Nakamura), T.M., K.K., S.F., A.A., S.N. (Shuhei Nishiguchi), K.H. Final approval: all authors. All authors have read and agreed to the published version of the manuscript.

Funding: This research received no external funding.

Acknowledgments: We would like to thank the medical staff in the second department of Osaka medical and pharmaceutical university for their support.

Conflicts of Interest: The authors declare no conflict of interest.

\section{References}

1. Cederholm, T.; Barazzoni, R.; Austin, P.; Ballmer, P.; Biolo, G.; Bischoff, S.; Compher, C.; Correia, I.; Higashiguchi, T.; Holst, M.; et al. ESPEN guidelines on definitions and terminology of clinical nutrition. Clin. Nutr. 2016, 36, 49-64. [CrossRef]

2. Rosenberg IH: Summary comments. Am. J. Clin. Nutr. 1989, 50, 1231-1233. [CrossRef]

3. Nishikawa, H.; Shiraki, M.; Hiramatsu, A.; Moriya, K.; Hino, K.; Nishiguchi, S. Japan Society of Hepatology guidelines for sarcopenia in liver disease (1st edition): Recommendation from the working group for creation of sarcopenia assessment criteria. Hepatol. Res. 2016, 46, 951-963. [CrossRef]

4. Cruz-Jentoft, A.J.; Bahat, G.; Bauer, J.; Boirie, Y.; Bruyère, O.; Cederholm, T.; Cooper, C.; Landi, F.; Rolland, Y.; Sayer, A.A.; et al. Writing Group for the European Working Group on Sarcopenia in Older People 2 (EWGSOP2), and the Extended Group for EWGSOP2. Sarcopenia: Revised European consensus on definition and diagnosis. Age Ageing 2019, 48, 16-31. [CrossRef] [PubMed] 
5. Chen, L.-K.; Woo, J.; Assantachai, P.; Auyeung, T.-W.; Chou, M.-Y.; Iijima, K.; Jang, H.C.; Kang, L.; Kim, M.; Kim, S.; et al. Asian Working Group for Sarcopenia: 2019 Consensus Update on Sarcopenia Diagnosis and Treatment. J. Am. Med. Dir. Assoc. 2020, 21, 300-307. [CrossRef]

6. Ungaro, R.; Mehandru, S.; Allen, P.B.; Peyrin-Biroulet, L.; Colombel, J.F. Ulcerative colitis. Lancet 2017, 389, 1756-1770. [CrossRef]

7. Kobayashi, T.; Siegmund, B.; Le Berre, C.; Wei, S.C.; Ferrante, M.; Shen, B.; Bernstein, C.N.; Danese, S.; Peyrin-Biroulet, L.; Hibi, T. Ulcerative colitis. Nat. Rev. Dis. Primers 2020, 6, 74. [CrossRef]

8. Torres, J.; Mehandru, S.; Colombel, J.F.; Peyrin-Biroulet, L. Crohn's disease. Lancet 2017, 389, 1741-1755. [CrossRef]

9. Roda, G.; Ng, S.C.; Kotze, P.G.; Argollo, M.; Panaccione, R.; Spinelli, A.; Kaser, A.; Peyrin-Biroulet, L.; Danese, S. Crohn's disease. Nat. Rev. Dis. Primers 2020, 6, 22. [CrossRef] [PubMed]

10. Shimizu, N.; Yoshikawa, N.; Ito, N.; Maruyama, T.; Suzuki, Y.; Takeda, S.-I.; Nakae, J.; Tagata, Y.; Nishitani, S.; Takehana, K.; et al. Crosstalk between Glucocorticoid Receptor and Nutritional Sensor mTOR in Skeletal Muscle. Cell Metab. 2011, 13, 170-182. [CrossRef] [PubMed]

11. Murakami, Y.; Nishiwaki, Y.; Oba, M.S.; Asakura, K.; Ohfuji, S.; Fukushima, W.; Suzuki, Y.; Nakamura, Y. Estimated prevalence of ulcerative colitis and Crohn's disease in Japan in 2014: An analysis of a nationwide survey. J. Gastroenterol. 2019, 54, 1070-1077. [CrossRef]

12. Scaldaferri, F.; Pizzoferrato, M.; Lopetuso, L.R.; Musca, T.; Ingravalle, F.; Sicignano, L.L.; Mentella, M.; Miggiano, G.; Mele, M.C.; Gaetani, E.; et al. Nutrition and IBD: Malnutrition and/or Sarcopenia? A Practical Guide. Gastroenterol. Res. Pract. 2017, 2017, 8646495. [CrossRef] [PubMed]

13. Ryan, E.; McNicholas, D.; Creavin, B.; Kelly, M.E.; Walsh, T.; Beddy, D. Sarcopenia and Inflammatory Bowel Disease: A Systematic Review. Inflamm. Bowel Dis. 2018, 25, 67-73. [CrossRef] [PubMed]

14. El Maghraoui, A.; Ebo'o, F.B.; Sadni, S.; Majjad, A.; Hamza, T.; Mounach, A. Is there a relation between pre-sarcopenia, sarcopenia, cachexia and osteoporosis in patients with ankylosing spondylitis? BMC Musculoskelet. Disord. 2016, 17, 268. [CrossRef] [PubMed]

15. Pizzoferrato, M.; De Sire, R.; Ingravalle, F.; Mentella, M.C.; Petito, V.; Martone, A.M.; Landi, F.; Miggiano, G.A.D.; Mele, M.C.; Lopetuso, L.R.; et al. Characterization of Sarcopenia in an IBD Population Attending an Italian Gastroenterology Tertiary Center. Nutrients 2019, 11, 2281. [CrossRef]

16. Turner, D.; Ricciuto, A.; Lewis, A.; D’Amico, F.; Dhaliwal, J.; Griffiths, A.M.; Bettenworth, D.; Sandborn, W.J.; Sands, B.E.; Reinisch, W.; et al. STRIDE-II: An Update on the Selecting Therapeutic Targets in Inflammatory Bowel Disease (STRIDE) Initiative of the International Organization for the Study of IBD (IOIBD): Determining Therapeutic Goals for Treat-to-Target strategies in IBD. Gastroenterology 2021, 160, 1570-1583. [CrossRef]

17. Ünal, N.G.; Oruç, N.; Tomey, O.; Özütemiz, A. Malnutrition and sarcopenia are prevalent among inflammatory bowel disease patients with clinical remission. Eur. J. Gastroenterol. Hepatol. 2021. [CrossRef]

18. Boparai, G.; Kedia, S.; Kandasamy, D.; Sharma, R.; Madhusudhan, K.S.; Dash, N.R.; Sahu, P.; Pal, S.; Sahni, P.; Panwar, R.; et al. Combination of sarcopenia and high visceral fat predict poor outcomes in patients with Crohn's disease. Eur. J. Clin. Nutr. 2021, 1-8. [CrossRef]

19. Ge, X.; Jiang, L.; Yu, W.; Wu, Y.; Liu, W.; Qi, W.; Cao, Q.; Bai, R.; Zhou, W. The importance of sarcopenia as a prognostic predictor of the clinical course in acute severe ulcerative colitis patients. Dig. Liver Dis. 2021, 53, 965-971. [CrossRef]

20. Celentano, V.; Kamil-Mustafa, L.; Beable, R.; Ball, C.; Flashman, K.G.; Jennings, Z.; Leary, D.P.O.; Higginson, A.; Luxton, S. Preoperative assessment of skeletal muscle mass during magnetic resonance enterography in patients with Crohn's disease. Updat. Surg. 2020, 73, 1419-1427. [CrossRef]

21. Lee, C.H.; Yoon, H.; Oh, D.J.; Lee, J.M.; Choi, Y.J.; Shin, C.M.; Park, Y.S.; Kim, N.; Lee, D.H.; Kim, J.S. The prevalence of sarcopenia and its effect on prognosis in patients with Crohn's disease. Intestig. Res. 2020, 18, 79-84. [CrossRef]

22. Grillot, J.; D’Engremont, C.; Parmentier, A.-L.; Lakkis, Z.; Piton, G.; Cazaux, D.; Gay, C.; De Billy, M.; Koch, S.; Borot, S.; et al. Sarcopenia and visceral obesity assessed by computed tomography are associated with adverse outcomes in patients with Crohn's disease. Clin. Nutr. 2020, 39, 3024-3030. [CrossRef]

23. Cushing, K.C.; Kordbacheh, H.; Gee, M.S.; Kambadakone, A.; Ananthakrishnan, A.N. Sarcopenia is a Novel Predictor of the Need for Rescue Therapy in Hospitalized Ulcerative Colitis Patients. J. Crohn's Colitis 2018, 12, 1036-1041. [CrossRef]

24. Mager, D.R.; Carroll, M.W.; Wine, E.; Siminoski, K.; Macdonald, K.; Kluthe, C.L.; Medvedev, P.; Chen, M.; Wu, J.; Turner, J.M.; et al. Vitamin D status and risk for sarcopenia in youth with inflammatory bowel diseases. Eur. J. Clin. Nutr. 2018, 72, 623-626. [CrossRef]

25. Thiberge, C.; Charpentier, C.; Gillibert, A.; Modzelewski, R.; Dacher, J.-N.; Savoye, G.; Savoye-Collet, C. Lower Subcutaneous or Visceral Adiposity Assessed by Abdominal Computed Tomography Could Predict Adverse Outcome in Patients with Crohn's Disease. J. Crohn's Colitis 2018, 12, 1429-1437. [CrossRef] [PubMed]

26. Dedhia, P.H.; White, Y.; Dillman, J.R.; Adler, J.; Jarboe, M.D.; Teitelbaum, D.H.; Hirschl, R.B.; Gadepalli, S. Reduced paraspinous muscle area is associated with post-colectomy complications in children with ulcerative colitis. J. Pediatr. Surg. 2017, 53, 477-482. [CrossRef]

27. Fujikawa, H.; Araki, T.; Okita, Y.; Kondo, S.; Kawamura, M.; Hiro, J.; Toiyama, Y.; Kobayashi, M.; Tanaka, K.; Inoue, Y.; et al. Impact of sarcopenia on surgical site infection after restorative proctocolectomy for ulcerative colitis. Surg. Today 2016, 47, 92-98. [CrossRef] 
28. Csontos, A.; Molnár, A.; Piri, Z.; Pálfi, E.; Miheller, P. Malnutrition risk questionnaire combined with body composition measurement in malnutrition screening in inflammatory bowel disease. Rev. Esp. Enferm. Dig. 2017, 109, 26-32. [CrossRef]

29. Holt, D.Q.; Moore, G.T.C.; Strauss, B.J.G.; Hamilton, A.L.; De Cruz, P.; Kamm, M.A. Visceral adiposity predicts post-operative Crohn's disease recurrence. Aliment. Pharmacol. Ther. 2017, 45, 1255-1264. [CrossRef]

30. Bamba, S.; Sasaki, M.; Takaoka, A.; Takahashi, K.; Imaeda, H.; Nishida, A.; Inatomi, O.; Sugimoto, M.; Andoh, A. Sarcopenia is a predictive factor for intestinal resection in admitted patients with Crohn's disease. PLoS ONE 2017, 12, e0180036. [CrossRef]

31. Zhang, T.; Ding, C.; Xie, T.; Yang, J.; Dai, X.; Lv, T.; Li, Y.; Gu, L.; Wei, Y.; Gong, J.; et al. Skeletal muscle depletion correlates with disease activity in ulcerative colitis and is reversed after colectomy. Clin. Nutr. 2016, 36, 1586-1592. [CrossRef] [PubMed]

32. Cravo, M.L.; Velho, S.; Torres, J.; Santos, M.P.C.; Palmela, C.; Cruz, R.; Strecht, J.; Maio, R.; Baracos, V. Lower skeletal muscle attenuation and high visceral fat index are associated with complicated disease in patients with Crohn's disease: An exploratory study. Clin. Nutr. ESPEN 2017, 21, 79-85. [CrossRef]

33. Nishikawa, H.; Yoh, K.; Enomoto, H.; Nishimura, T.; Nishiguchi, S.; Iijima, H. Clinical impact of the finger-circle test in patients with liver diseases. Hepatol. Res. 2021, 51, 603-613. [CrossRef] [PubMed]

34. Spooren, C.E.G.M.; Lodewick, T.M.; Beelen, E.M.J.; van Dijk, D.P.J.; Bours, M.J.L.; Haans, J.J.; Masclee, A.A.M.; Pierik, M.J.; Bakers, F.C.H.; Jonkers, D.M.A.E. The reproducibility of skeletal muscle signal intensity on routine magnetic resonance imaging in Crohn's disease. J. Gastroenterol. Hepatol. 2020, 35, 1902-1908. [CrossRef] [PubMed]

35. Ashton, J.J.; Peiris, D.; Green, Z.; Johnson, M.J.; Marino, L.V.; Griffiths, M.; Beattie, R.M. Routine abdominal magnetic resonance imaging can determine psoas muscle area in paediatric Crohn's disease and correlates with bioelectrical impedance spectroscopy measures of lean mass. Clin. Nutr. ESPEN 2021, 42, 233-238. [CrossRef] [PubMed]

36. Jeejeebhoy, K.N.; Duerksen, D.R. Malnutrition in Gastrointestinal Disorders: Detection and Nutritional Assessment. Gastroenterol. Clin. N. Am. 2018, 47, 1-22. [CrossRef]

37. Clark, R.; Johnson, R. Malabsorption Syndromes. Nurs. Clin. N. Am. 2018, 53, 361-374. [CrossRef]

38. Nishikawa, H.; Enomoto, H.; Nishiguchi, S.; Iijima, H. Liver Cirrhosis and Sarcopenia from the Viewpoint of Dysbiosis. Int. J. Mol. Sci. 2020, 21, 5254. [CrossRef] [PubMed]

39. Martínez-Arnau, F.M.; Vivas, R.F.; Buigues, C.; Castillo, Y.; Molina, P.; Hoogland, A.J.; Van Doesburg, F.; Pruimboom, L.; Fernández-Garrido, J.; Cauli, O. Effects of Leucine Administration in Sarcopenia: A Randomized and Placebo-controlled Clinical Trial. Nutrients 2020, 12, 932. [CrossRef]

40. Harbord, M.; Annese, V.; Vavricka, S.R.; Allez, M.; Acosta, M.B.-D.; Boberg, K.M.; Burisch, J.; De Vos, M.; De Vries, A.-M.; Dick, A.D.; et al. The First European Evidence-Based Consensus on Extra-Intestinal Manifestations in Inflammatory Bowel Disease. J. Crohn's Colitis 2015, 10, 239-254. [CrossRef]

41. Van Dronkelaar, C.; Van Velzen, A.; Abdelrazek, M.; Van Der Steen, A.; Weijs, P.; Tieland, M. SUN-P297: The Role of Calcium, Iron, Magnesium, Phosphorus, Potassium, Selenium, Sodium, and Zinc on Muscle Mass, Muscle Strength, and Physical Performance in Older Adults: A Systematic Review. Clin. Nutr. 2017, 36, S163. [CrossRef]

42. Nishikawa, H.; Enomoto, H.; Yoh, K.; Iwata, Y.; Sakai, Y.; Kishino, K.; Ikeda, N.; Takashima, T.; Aizawa, N.; Takata, R.; et al. Serum Zinc Concentration and Sarcopenia: A Close Linkage in Chronic Liver Diseases. J. Clin. Med. 2019, 8, 336. [CrossRef] [PubMed]

43. Weisshof, R.; Chermesh, I. Micronutrient deficiencies in inflammatory bowel disease. Curr. Opin. Clin. Nutr. Metab. Care 2015, 18, 576-581. [CrossRef]

44. Wallace, K.L.; Zheng, L.B.; Kanazawa, Y.; Shih, D.Q. Immunopathology of inflammatory bowel disease. World J. Gastroenterol. 2014, 20, 6-21. [CrossRef]

45. Adams, V.; Linke, A.; Wisloff, U.; Döring, C.; Erbs, S.; Kränkel, N.; Witt, C.C.; Labeit, S.; Müller-Werdan, U.; Schuler, G.; et al. Myocardial expression of Murf-1 and MAFbx after induction of chronic heart failure: Effect on myocardial contractility. Cardiovasc. Res. 2007, 73, 120-129. [CrossRef]

46. Yao, D.; Dong, M.; Dai, C.; Wu, S. Inflammation and Inflammatory Cytokine Contribute to the Initiation and Development of Ulcerative Colitis and Its Associated Cancer. Inflamm. Bowel Dis. 2019, 25, 1595-1602. [CrossRef] [PubMed]

47. Casadonte, C.J.L.; Brown, J.; Strople, J.; Neighbors, K.; Fei, L.; Alonso, E.M. Low Insulin-like Growth Factor-1 Influences Fatigue and Quality of Life in Children with Inflammatory Bowel Disease. J. Pediatr. Gastroenterol. Nutr. 2018, 67, 616-621. [CrossRef] [PubMed]

48. DiFedele, L.M.; He, J.; Bonkowski, E.L.; Han, X.; Held, M.A.; Bohan, A.; Menon, R.K.; Denson, L.A. Tumor Necrosis Factor $\alpha$ Blockade Restores Growth Hormone Signaling in Murine Colitis. Gastroenterology 2005, 128, 1278-1291. [CrossRef]

49. Van Langenberg, D.R.; Gatta, P.D.; Warmington, S.A.; Kidgell, D.J.; Gibson, P.R.; Russell, A.P. Objectively measured muscle fatigue in Crohn's disease: Correlation with self-reported fatigue and associated factors for clinical application. J. Crohn's Colitis 2014, 8, 137-146. [CrossRef]

50. Street, M.E.; De'Angelis, G.; Camacho-Hübner, C.; Giovannelli, G.; Ziveri, M.A.; Bacchini, P.L.; Bernasconi, S.; Sansebastiano, G.; Savage, M.O. Relationships between Serum IGF-1, IGFBP-2, Interleukin-1Beta and Interleukin-6 in Inflammatory Bowel Disease. Horm. Res. Paediatr. 2004, 61, 159-164. [CrossRef]

51. Li, F.; Li, Y.; Duan, Y.; Hu, C.-A.A.; Tang, Y.; Yin, Y. Myokines and adipokines: Involvement in the crosstalk between skeletal muscle and adipose tissue. Cytokine Growth Factor Rev. 2016, 33, 73-82. [CrossRef] 
52. Mao, R.; Kurada, S.; Gordon, I.O.; Baker, M.E.; Gandhi, N.; McDonald, C.; Coffey, J.C.; Rieder, F. The Mesenteric Fat and Intestinal Muscle Interface: Creeping Fat Influencing Stricture Formation in Crohn's Disease. Inflamm. Bowel Dis. 2018, 25, 421-426. [CrossRef]

53. Bryant, R.V.; Schultz, C.G.; Ooi, S.; Goess, C.; Costello, S.P.; Vincent, A.D.; Schoeman, S.N.; Lim, A.; Bartholomeusz, F.D.; Travis, S.P.; et al. Obesity in Inflammatory Bowel Disease: Gains in Adiposity despite High Prevalence of Myopenia and Osteopenia. Nutrients 2018, 10, 1192. [CrossRef]

54. Adams, D.W.; Gurwara, S.; Silver, H.J.; Horst, S.N.; Beaulieu, D.B.; Schwartz, D.A.; Seidner, D.L. Sarcopenia Is Common in Overweight Patients with Inflammatory Bowel Disease and May Predict Need for Surgery. Inflamm. Bowel Dis. 2017, 23, 1182-1186. [CrossRef] [PubMed]

55. Takahashi, Y.; Sato, S.; Kurashima, Y.; Lai, C.-Y.; Otsu, M.; Hayashi, M.; Yamaguchi, T.; Kiyono, H. Reciprocal Inflammatory Signaling between Intestinal Epithelial Cells and Adipocytes in the Absence of Immune Cells. EBioMedicine 2017, 23, 34-45. [CrossRef] [PubMed]

56. Remelli, F.; Vitali, A.; Zurlo, A.; Volpato, S. Vitamin D Deficiency and Sarcopenia in Older Persons. Nutrients 2019, $11,2861$. [CrossRef] [PubMed]

57. Uchitomi, R.; Oyabu, M.; Kamei, Y. Vitamin D and Sarcopenia: Potential of Vitamin D Supplementation in Sarcopenia Prevention and Treatment. Nutrients 2020, 12, 3189. [CrossRef]

58. Fletcher, J.; Cooper, S.C.; Ghosh, S.; Hewison, M. The Role of Vitamin D in Inflammatory Bowel Disease: Mechanism to Management. Nutrients 2019, 11, 1019. [CrossRef]

59. Bass, J.J.; Nakhuda, A.; Deane, C.S.; Brook, M.S.; Wilkinson, D.J.; Phillips, B.E.; Philp, A.; Tarum, J.; Kadi, F.; Andersen, D.; et al. Overexpression of the vitamin D receptor (VDR) induces skeletal muscle hypertrophy. Mol. Metab. 2020, 42, 101059. [CrossRef] [PubMed]

60. Ashcroft, S.P.; Bass, J.J.; Kazi, A.A.; Atherton, P.J.; Philp, A. The vitamin D receptor regulates mitochondrial function in C2C12 myoblasts. Am. J. Physiol. Physiol. 2020, 318, C536-C541. [CrossRef] [PubMed]

61. Daussin, F.N.; Boulanger, E.; Lancel, S. From mitochondria to sarcopenia: Role of inflammaging and RAGE-ligand axis implication. Exp. Gerontol. 2021, 146, 111247. [CrossRef] [PubMed]

62. Agrawal, D.; Yin, K. Vitamin D and inflammatory diseases. J. Inflamm. Res. 2014, 7, 69-87. [CrossRef]

63. Skrzypczak, D.; Ratajczak, A.E.; Szymczak-Tomczak, A.; Dobrowolska, A.; Eder, P.; Krela-Kaźmierczak, I. A Vicious Cycle of Osteosarcopeniain Inflammatory Bowel Diseases-Aetiology, Clinical Implications and Therapeutic Perspectives. Nutrients 2021, 13, 293. [CrossRef]

64. Olmedo-Martín, R.V.; González-Molero, I.; Olveira, G.; Amo-Trillo, V.; Jiménez-Pérez, M. Vitamin D in Inflammatory Bowel Disease: Biological, Clinical and Therapeutic Aspects. Curr. Drug Metab. 2019, 20, 390-398. [CrossRef] [PubMed]

65. Parian, A.; Limketkai, B.N. Dietary Supplement Therapies for Inflammatory Bowel Disease: Crohn's Disease and Ulcerative Colitis. Curr. Pharm. Des. 2016, 22, 180-188. [CrossRef]

66. Guan, Y.; Hao, Y.; Guan, Y.; Bu, H.; Wang, H. Effects of vitamin D supplementation on blood markers in ulcerative colitis patients: A systematic review and meta-analysis. Eur. J. Nutr. 2021, 1-13. [CrossRef]

67. Bousvaros, A.; Zurakowski, D.; Duggan, C.; Law, T.; Rifai, N.; Goldberg, N.E.; Leichtner, A.M. Vitamins A and E Serum Levels in Children and Young Adults with Inflammatory Bowel Disease: Effect of Disease Activity. J. Pediatr. Gastroenterol. Nutr. 1998, 26, 129-135. [CrossRef] [PubMed]

68. Kabbani, T.A.; Koutroubakis, I.; Schoen, R.E.; Ramos-Rivers, C.; Shah, N.; Swoger, J.; Regueiro, M.; Barrie, A.; Schwartz, M.; Hashash, J.G.; et al. Association of Vitamin D Level with Clinical Status in Inflammatory Bowel Disease: A 5-Year Longitudinal Study. Am. J. Gastroenterol. 2016, 111, 712-719. [CrossRef]

69. Bulut, E.A.; Soysal, P.; Aydin, A.E.; Dokuzlar, O.; Kocyigit, S.E.; Isik, A.T. Vitamin B12 deficiency might be related to sarcopenia in older adults. Exp. Gerontol. 2017, 95, 136-140. [CrossRef] [PubMed]

70. Lochlainn, M.N.; Bowyer, R.C.E.; Steves, C.J. Dietary Protein and Muscle in Aging People: The Potential Role of the Gut Microbiome. Nutrients 2018, 10, 929. [CrossRef]

71. Oliphant, K.; Allen-Vercoe, E. Macronutrient metabolism by the human gut microbiome: Major fermentation by-products and their impact on host health. Microbiome 2019, 7, 91. [CrossRef]

72. Ticinesi, A.; Lauretani, F.; Milani, C.; Nouvenne, A.; Tana, C.; Del Rio, D.; Maggio, M.; Ventura, M.; Meschi, T. Aging Gut Microbiota at the Cross-Road between Nutrition, Physical Frailty, and Sarcopenia: Is There a Gut-Muscle Axis? Nutrients 2017, 9 , 1303. [CrossRef] [PubMed]

73. Sartor, R.B. Microbial Influences in Inflammatory Bowel Diseases. Gastroenterology 2008, 134, 577-594. [CrossRef] [PubMed]

74. Tabrizi, R.; Hallajzadeh, J.; Mirhosseini, N.; Lankarani, K.B.; Maharlouei, N.; Akbari, M.; Asemi, Z. The effects of vitamin D supplementation on muscle function among postmenopausal women: A systematic review and meta-analysis of randomized controlled trials. EXCLI J. 2019, 18, 591-603. [PubMed]

75. Picca, A.; Fanelli, F.; Calvani, R.; Mule, G.; Pesce, V.; Sisto, A.; Pantanelli, C.; Bernabei, R.; Landi, F.; Marzetti, E. Gut Dysbiosis and Muscle Aging: Searching for Novel Targets against Sarcopenia. Mediat. Inflamm. 2018, 2018, 7026198. [CrossRef] [PubMed]

76. De Sire, R.; Rizzatti, G.; Ingravalle, F.; Pizzoferrato, M.; Petito, V.; Lopetuso, L.; Graziani, C.; De Sire, A.; Mentella, M.C.; Mele, M.C.; et al. Skeletal muscle-gut axis: Emerging mechanisms of sarcopenia for intestinal and extra intestinal diseases. Minerva Gastroenterol. Dietol. 2018, 64, 351-362. [CrossRef] 
77. Nishida, A.; Inoue, R.; Inatomi, O.; Bamba, S.; Naito, Y.; Andoh, A. Gut microbiota in the pathogenesis of inflammatory bowel disease. Clin. J. Gastroenterol. 2017, 11, 1-10. [CrossRef] [PubMed]

78. Ohkusa, T.; Yoshida, T.; Sato, N.; Watanabe, S.; Tajiri, H.; Okayasu, I. Commensal bacteria can enter colonic epithelial cells and induce proinflammatory cytokine secretion: A possible pathogenic mechanism of ulcerative colitis. J. Med. Microbiol. 2009, 58, 535-545. [CrossRef]

79. Ohkusa, T.; Okayasu, I.; Ogihara, T.; Morita, K.; Ogawa, M.; Sato, N. Induction of experimental ulcerative colitis by Fusobacterium varium isolated from colonic mucosa of patients with ulcerative colitis. Gut 2003, 52, 79-83. [CrossRef]

80. Atlan, L.; Cohen, S.; Shiran, S.; Ben Sira, L.; Pratt, L.-T.; Yerushalmy-Feler, A. Sarcopenia is a Predictor for Adverse Clinical Outcome in Pediatric Inflammatory Bowel Disease. J. Pediatr. Gastroenterol. Nutr. 2021, 72, 883-888. [CrossRef] [PubMed]

81. Bamba, S.; Inatomi, O.; Takahashi, K.; Morita, Y.; Imai, T.; Ohno, M.; Kurihara, M.; Takebayashi, K.; Kojima, M.; Iida, H.; et al. Assessment of Body Composition from CT Images at the Level of the Third Lumbar Vertebra in Inflammatory Bowel Disease. Inflamm. Bowel Dis. 2020, 27, 1435-1442. [CrossRef] [PubMed]

82. Zager, Y.; Khalilieh, S.; Ganaiem, O.; Gorgov, E.; Horesh, N.; Anteby, R.; Kopylov, U.; Jacoby, H.; Dreznik, Y.; Dori, A.; et al. Low psoas muscle area is associated with postoperative complications in Crohn's disease. Int. J. Color. Dis. 2020, 36, 543-550. [CrossRef]

83. Galata, C.; Hodapp, J.; Weiß, C.; Karampinis, I.; Vassilev, G.; Reißfelder, C.; Otto, M. Skeletal Muscle Mass Index Predicts Postoperative Complications in Intestinal Surgery for Crohn's Disease. JPEN J. Parenter. Enter. Nutr. 2020, 44, 714-721. [CrossRef]

84. O'Brien, S.; Kavanagh, R.G.; Carey, B.W.; Maher, M.M.; O'Connor, O.J.; Andrews, E.J. The impact of sarcopenia and myosteatosis on postoperative outcomes in patients with inflammatory bowel disease. Eur. Radiol. Exp. 2018, 2, 37. [CrossRef]

85. Pedersen, M.; Cromwell, J.; Nau, P. Sarcopenia is a Predictor of Surgical Morbidity in Inflammatory Bowel Disease. Inflamm. Bowel Dis. 2017, 23, 1867-1872. [CrossRef] [PubMed]

86. Zhang, T.; Cao, L.; Cao, T.; Yang, J.; Gong, J.; Zhu, W.; Li, N.; Li, J. Prevalence of Sarcopenia and Its Impact on Postoperative Outcome in Patients with Crohn's Disease Undergoing Bowel Resection. J. Parenter. Enter. Nutr. 2015, 41, 592-600. [CrossRef] [PubMed]

87. Bryant, R.V.; Ooi, S.; Schultz, C.G.; Goess, C.; Grafton, R.; Hughes, J.; Lim, A.; Bartholomeusz, F.D.; Andrews, J.M. Low muscle mass and sarcopenia: Common and predictive of osteopenia in inflammatory bowel disease. Aliment. Pharmacol. Ther. 2015, 41, 895-906. [CrossRef]

88. Kang, M.K.; Kim, K.O.; Kim, M.C.; Gil Park, J.; Jang, B.I. Sarcopenia Is a New Risk Factor of Nonalcoholic Fatty Liver Disease in Patients with Inflammatory Bowel Disease. Dig. Dis. 2020, 38, 507-514. [CrossRef] [PubMed]

89. Singh, S.; Dulai, P.S.; Zarrinpar, A.; Ramamoorthy, S.; Sandborn, W.J. Obesity in IBD: Epidemiology, pathogenesis, disease course and treatment outcomes. Nat. Rev. Gastroenterol. Hepatol. 2016, 14, 110-121. [CrossRef]

90. Komoto, S.; Higashiyama, M.; Watanabe, C.; Suzuki, Y.; Watanabe, M.; Hibi, T.; Takebayashi, T.; Asakura, K.; Nishiwaki, Y.; Miura, S.; et al. Clinical differences between elderly-onset ulcerative colitis and non-elderly-onset ulcerative colitis: A nationwide survey data in Japan. J. Gastroenterol. Hepatol. 2018, 33, 1839-1843. [CrossRef]

91. Taleban, S.; Colombel, J.-F.; Mohler, M.J.; Fain, M.J. Inflammatory Bowel Disease and the Elderly: A Review. J. Crohn's Colitis 2015, 9, 507-515. [CrossRef] [PubMed]

92. Satake, S.; Arai, H. Implications of frailty screening in clinical practice. Curr. Opin. Clin. Nutr. Metab. Care 2017, 20, 4-10. [CrossRef] [PubMed]

93. Singh, S.; Heien, H.C.; Sangaralingham, L.; Shah, N.D.; Lai, J.C.; Sandborn, W.J.; Moore, A.A. Frailty and Risk of Serious Infections in Biologic-treated Patients with Inflammatory Bowel Diseases. Inflamm. Bowel Dis. 2020, izaa327. [CrossRef] [PubMed]

94. Qian, A.S.; Nguyen, N.H.; Elia, J.; Ohno-Machado, L.; Sandborn, W.J.; Singh, S. Frailty Is Independently Associated with Mortality and Readmission in Hospitalized Patients with Inflammatory Bowel Diseases. Clin. Gastroenterol. Hepatol. 2020. [CrossRef]

95. Kochar, B.; Cai, W.; Cagan, A.; Ananthakrishnan, A.N. Pretreatment Frailty Is Independently Associated with Increased Risk of Infections after Immunosuppression in Patients with Inflammatory Bowel Diseases. Gastroenterology 2020, 158, 2104-2111.e2. [CrossRef]

96. Bellone, F.; Sardella, A.; Muscianisi, M.; Basile, G. Fatigue, sarcopenia, and frailty in older adults with Inflammatory Bowel Disease. Minerva Gastroenterol. 2021. [CrossRef]

97. Asscher, V.E.R.; Lee-Kong, F.V.Y.; Kort, E.D.; Van Deudekom, F.J.; Mooijaart, S.P.; Maljaars, J. Systematic Review: Components of a Comprehensive Geriatric Assessment in Inflammatory Bowel Disease-A Potentially Promising but often Neglected Risk Stratification. J. Crohn's Colitis 2019, 13, 1418-1432. [CrossRef]

98. Beckwée, D.; Sarcopenia Guidelines Development Group of the Belgian Society of Gerontology and Geriatrics (BSGG); Delaere, A.; Aelbrecht, S.; Baert, V.; Beaudart, C.; Bruyere, O.; De Saint-Hubert, M.; Bautmans, I. Exercise Interventions for the Prevention and Treatment of Sarcopenia. A Systematic Umbrella Review. J. Nutr. Health Aging 2019, 23, 494-502. [CrossRef] [PubMed]

99. Forbes, A.; Escher, J.; Hébuterne, X.; Kłęk, S.; Krznaric, Z.; Schneider, S.; Shamir, R.; Stardelova, K.; Wierdsma, N.; Wiskin, A.E.; et al. ESPEN guideline: Clinical nutrition in inflammatory bowel disease. Clin. Nutr. 2016, 36, 321-347. [CrossRef]

100. Aksan, A.; Farrag, K.; Blumenstein, I.; Schröder, O.; Dignass, A.U.; Stein, J. Chronic intestinal failure and short bowel syndrome in Crohn's disease. World J. Gastroenterol. 2021, 27, 3440-3465. [CrossRef] [PubMed]

101. Lopez, P.; Pinto, R.S.; Radaelli, R.; Rech, A.; Grazioli, R.; Izquierdo, M.; Cadore, E. Benefits of resistance training in physically frail elderly: A systematic review. Aging Clin. Exp. Res. 2017, 30, 889-899. [CrossRef] 
102. Das, D.K.; Graham, Z.A.; Cardozo, C.P. Myokines in skeletal muscle physiology and metabolism: Recent advances and future perspectives. Acta Physiol. 2019, 228, e13367. [CrossRef] [PubMed]

103. Eckert, K.G.; Abbasi-Neureither, I.; Köppel, M.; Huber, G. Structured physical activity interventions as a complementary therapy for patients with inflammatory bowel disease-A scoping review and practical implications. BMC Gastroenterol. $2019,19,115$. [CrossRef] [PubMed]

104. Klare, P.; Nigg, J.; Nold, J.; Haller, B.; Krug, A.; Mair, S.; Thoeringer, C.K.; Christle, J.; Schmid, R.M.; Halle, M.; et al. The Impact of a Ten-Week Physical Exercise Program on Health-Related Quality of Life in Patients with Inflammatory Bowel Disease: A Prospective Randomized Controlled Trial. Digestion 2015, 91, 239-247. [CrossRef] [PubMed]

105. Ploeger, H.; Obeid, J.; Nguyen, T.; Takken, T.; Issenman, R.; de Greef, M.; Timmons, B. Exercise and Inflammation in Pediatric Crohn's Disease. Int. J. Sport. Med. 2012, 33, 671-679. [CrossRef] [PubMed]

106. Ng, V.; Millard, W.; Lebrun, C.; Howard, J. Low-Intensity Exercise Improves Quality of Life in Patients with Crohn's Disease. Clin. J. Sport Med. 2007, 17, 384-388. [CrossRef] [PubMed]

107. Sigurdsson, G.V.; Schmidt, S.; Mellström, D.; Ohlsson, C.; Karlsson, M.; Lorentzon, M.; Saalman, R. Physical exercise is associated with beneficial bone mineral density and body composition in young adults with childhood-onset inflammatory bowel disease. Scand. J. Gastroenterol. 2021, 56, 699-707. [CrossRef] [PubMed]

108. Seeger, W.A.; Thieringer, J.; Esters, P.; Allmendinger, B.; Stein, J.; Schulze, H.; Dignass, A. Moderate endurance and muscle training is beneficial and safe in patients with quiescent or mildly active Crohn's disease. United Eur. Gastroenterol. J. 2020, 8, 804-813. [CrossRef] [PubMed]

109. Jones, K.; Baker, K.; Speight, R.A.; Thompson, N.P.; Tew, G.A. Randomised clinical trial: Combined impact and resistance training in adults with stable Crohn's disease. Aliment. Pharmacol. Ther. 2020, 52, 964-975. [CrossRef]

110. Subramaniam, K.; Fallon, K.; Ruut, T.; Lane, D.; McKay, R.; Shadbolt, B.; Ang, S.; Cook, M.; Platten, J.; Pavli, P.; et al. Infliximab reverses inflammatory muscle wasting (sarcopenia) in Crohn's disease. Aliment. Pharmacol. Ther. 2015, 41, 419-428. [CrossRef]

111. El Hajj, C.; Fares, S.; Chardigny, J.M.; Boirie, Y.; Walrand, S. Vitamin D supplementation and muscle strength in pre-sarcopenic elderly Lebanese people: A randomized controlled trial. Arch. Osteoporos. 2018, 14, 4. [CrossRef] [PubMed]

112. Tomlinson, P.B.; Joseph, C.; Angioi, M. Effects of vitamin D supplementation on upper and lower body muscle strength levels in healthy individuals. A systematic review with meta-analysis. J. Sci. Med. Sport 2015, 18, 575-580. [CrossRef] [PubMed]

113. Hradsky, O.; Soucek, O.; Maratova, K.; Matyskova, J.; Čopová, I.; Zarubova, K.; Bronsky, J.; Sumnik, Z. Supplementation with 2000 IU of Cholecalciferol Is Associated with Improvement of Trabecular Bone Mineral Density and Muscle Power in Pediatric Patients with IBD. Inflamm. Bowel Dis. 2017, 23, 514-523. [CrossRef] [PubMed]

114. Battistini, C.; Ballan, R.; Herkenhoff, M.; Saad, S.; Sun, J. Vitamin D Modulates Intestinal Microbiota in Inflammatory Bowel Diseases. Int. J. Mol. Sci. 2020, 22, 362. [CrossRef] [PubMed] 